\title{
PEASANT MEMORY AND ORAL HISTORY: A NOTE ON METHODOLOGY
}

The oral history data for this book were derived mainly from the library of peasant memory. Most of them are from field research focused on three counties (Puyang, Huaxian, and Nanle) and three towns (Puyang, Dao Kou, and Nanle) in the section of the North China plain just north of the Yellow River, where the provinces of Hebei, Shandong, and Henan converge. Building on Anne L. Craig's work, ${ }^{1}$ I have tapped the remembered life histories of some two hundred participants in a major protest movement and drawn on one thousand hours of interviews between 1985 and 1993 in the rural villages of Qian Kou, Qi Ji, Fanzhuang, and Qian Foji and in Cheng Guan and San Huang, both located within county towns. Borrowing from Paul R. Connerton's How Societies Remember, ${ }^{2}$ I have recorded peasant "habitmemory," that is, remembrances of performances associated with habitual practices, to illuminate popular forms of resistance that became entangled with CCP-led revolution.

Western scholarship on the origins and nature of the pre-1949 revolution in rural China relies upon inscription, but this process is verbal, not inscribed. The peasant saltmakers in Salt of the Earth speak to us from brains stockpiled with information on how they performed socially and politically in Republican times. Yet why, if the memory of habitual practice is so prevalent in the countryside, is study of the October 1 revolution via this form of memory virtually nonexistent? The answer-which supersedes both the cold war loss of access to rural China and the Communist Party's ideological representation of the place of the country people in the modern revolution-is so fundamental that it has eluded us. Many of the politicians who played leading parts in the CCP-led revolutionary struggle were themselves 
country folk who simply were not accustomed to recording their deeds and thoughts: their popularity and political credibility in folk society were acknowledged mainly within the framework of local oral tradition. At the same time, many of the CCP leaders were too busy seeking ways to speed the development of China after 1949, too caught up in the crises of the Korean War, the Great Leap Forward, and the Sino-Soviet split, to write of the interplay between their party's revolutionary history and folk political tradition. Salt of the Earth is an attempt to retrieve this interplay.

Peasant memory is an important source of historical information about the unknown cast of folk characters who played a role in the pre-1949 revolution -their relations with local community, their lifestyles, their religious traditions and political sentiments, and especially the extent to which they aligned with the CCP. ${ }^{3}$ The justification for rediscovering the October i revolution through peasant memory goes beyond well-founded skepticism about the doctrinaire slant of CCP history to the cultural gap between the peasantry and the ruling national elite, which is composed in part of partytrained intellectuals living in cities and capitals far removed from villages in the remote areas where the revolution was based. Socially and culturally distanced from peasant life, these party scholars carry a host of biases. Indeed, such historians have little predisposition to explore the pre-1949 participation of the peasantry from the standpoint of the folk societies and folk cultures that helped shape and define popular commitments to the CCP and its revolutionary program. Perceiving country folk as illiterate, dirty, impulsive, mentally incompetent, and ridden with ridiculous fairy tales, these historians are repulsed by the notion that folk interests and ideas both inspired and invigorated the CCP-orchestrated revolutionary process. Most of them, ignoring peasant memory, delight in consulting written party records and party materials on revolutionary history, seldom questioning whether these are in accord with the remembered history of village people.

Inasmuch as peasant memory reflects the habitual interest-serving performance of a common group of country people, it is a form of memory that usually is retrieved within a localized framework of community history ${ }^{4}$ and thus has a logic that is not merely the product of the national historical moments or international political events that have framed the recollections of the October 1 revolution for the regional and national leaders of the Communist Party. As Connerton points out in reference to Carlo Levi's 1935 political exile to an Italian village, members of two separate groups who participate in the same event often place their memory of that event in significantly different frameworks. ${ }^{5}$ Levi took special note of the inscribed commemoratives to the local martyrs of World War I, but he also discovered that peasants did not even speak of the Great War and had no memory of it as a critical event. The war they did remember was "the war of the brigands" 
with the government. ${ }^{6}$ This previous war, in comparison to World War I, had left a permanent imprint on their collective identity. Similarly, I found that peasants did not assign the same importance to the definitive historical event that shaped the political identity of many of the CCP leaders who formed the revolutionary Hebei-Shandong-Henan border area government during WWII: the Japanese invasion and the War of Resistance. To be sure, the War of Resistance was important to many village people; but for the great majority its significance paled in comparison to the remembrances of a war against the police instrument of Kuomintang fiscal order. This latter war preceded, intersected with, and persisted beyond the CCP-led War of Resistance and, in many respects, posed a greater challenge to the permanency of peasant life and culture.

The politicization of the peasantry by the CCP, and of the historiography of the October 1 revolution by centrally placed party theoreticians who became the guardians of popular revolutionary history after 1949, both diminished and debased the ways in which pre-1949 local Communist leaders acted in accordance with folk ideas and initiatives. Once the MarxistLeninist theoreticians began to establish their hegemony within the partystate, and perfected their ideologically neat representations of the revolutionary epoch, it became politically dangerous for the local Communist leaders of the pre-1949 regional and national revolutionary process to write down their insights into how the rural folk had influenced, and sometimes invigorated, the CCP-led insurgency. Local popular memory of everyday revolutionary politics gave way to distortion, silence, and hesitancy to publish oral history findings that were not in harmony with correct party history lines. In myriad ways, this kind of party hegemony has worked to prevent us from entering the pre-1 949 revolution via peasant memory. I encountered three examples of this phenomenon. (1) In interviewing peasants in Hua County I discovered that the provincial-level party historians presented the local popular struggle over salt as having been staged under the leadership of the CCP, when in peasant memory, it was clearly the product of local village leaders who were the allies of, but not members of, the party. (2) While interviewing Beijing-based CCP leaders who formerly had been intimately connected with the peasant saltmakers in Puyang, I learned that not only had they not discussed their pre-1949 history with foreigners, but they had not even discussed it with homegrown Chinese historians from Puyang itself, fearing that their reminiscences would not resonate with post1949 Central Committee historiography. (3) In interviewing peasants in Nanle County I found that the most knowledgeable local historian of the popular struggle I was studying had begun his own village oral history project on this topic, but only in 1979, after the CCP reformers had defeated the antimarket radicals in the party hierarchy. He had yet to publish his 
voluminous raw notes, partly because the peasant memory they contained did not fit neatly into the categories of high-level party historians.

In collecting data for Salt of the Earth I have followed several methodological procedures, each undertaken to depoliticize the interviews and to maximize the reliability of information derived from them. First, in order to avoid ending up with an extremely biased sample of preselected villages where the CCP was firmly entrenched and where the party leaders could recast local social history and revise the political history of the pre-1949 period, I insisted on the right to choose the "protest villages" in which I conducted oral history research. I selected Qian Kou village in Puyang in consultation with my hosts; I chose Qi Ji, Fanzhuang, and Qian Foji and the other village interview sites after reading about them in internally restricted CCP documents or after picking up information about them from peasants in other border area villages. As a rule, my hosts did not go to these villages with me, especially after my second trip in June, 1987 , for they were not interested in learning the revolutionary history of the rural people and did not want to endure the hardships of research in the outlying villages. Usually, no PRC authorities (university hosts, foreign affairs bureau officials, or local county historians) accompanied me to monitor my interviews. Nor did my hosts call villagers, or village leaders, to party offices to "prepare" them to give politically correct answers to my questions. At my invitation, Mr. Shi Guoqiang of the Nanle County Local History Office accompanied me to Fanzhuang once, to San Huang twice, and to Qian Foji once. My Chinese research assistant was with me 70 percent of the time; otherwise, I was alone with local people.

A second ticklish question arose: how could one be confident that the momentary "party line" did not shape the stories peasants thought an interviewer should hear? To avoid relying on a biased sample of preselected and pretutored individuals who gained political credit either by parroting the CCP pro-market line of the 198 os or by recalling more bitter suffering under the Kuomintang than their neighbors, I got permission to select my own respondents without interference from my university hosts or village party leaders. For the most part, I chose interview subjects by the technique of "snowball sampling" outlined by Earl R. Babbie. ${ }^{7}$ My previously interviewed informants helped me build up a network of local people who had participated in, witnessed, or somehow knew about antistate protest at the village, market, and county levels in the 1930s. This technique permitted me to comprehend past changes from the perspective of villagers from all walks of life and from different lineages and to build up a data base that avoided the pitfalls of CCP-controlled sampling. In eight different trips to the countryside, I interviewed two hundred rural people through in-depth household talks and small-group discussions. Approximately half had participated directly in the saltmakers' struggle of the 193os, and another 25 
percent were from households whose members had supported, or sympathized with, that struggle. Approximately 22 percent of the peasant salt producers, peddlers, and purchase agents interviewed had become members of the Chinese Communist Party prior to $1949 ; 7^{8}$ percent had no history of party involvement. Furthermore, many of these peasant interviewees had resisted the post-1949 antimarket campaigns of the CCP-directed state, so that they hardly needed a party line to structure their preferences for market freedom.

I interviewed the majority of respondents in their homes, either alone or with a few family members present. In talking with individual peasants about their relations with the protest movement under study, I placed them within the framework of family memory, for as Maurice Halbwachs has pointed out, ${ }^{8}$ peasants are inclined to remember their individual history as part of a pattern of interaction with family. I wanted to see if the struggle with the Kuomintang state was, at bottom, a struggle of members of kinship groups sharing habits that the state was harming, and I wanted to elicit responses anchored in the interior of peasant memory, which I believe is to a significant extent walled off from the propaganda of the party. In all of these household interviews, therefore, I went to great lengths to detect, avoid, and get beyond the "stilted responses" of peasants skilled in the rituals of Maoist recall and attempted to create a climate in which CCP-prepared scripts did not structure responses. The dialogue was, following David W. Sabean, ${ }^{9}$ objectively focused on a balanced search for how villagers themselves perceived and defined their proprietary rights and market prerogatives and how they created a discourse among themselves over the attempts of state revenue forces to sacrifice these rights and prerogatives to the fiscal drives of top-level policy makers in Chiang Kai-shek's central government.

Approximately 70 percent of my interviews were conducted in peasant households, and I had permission to go to any household I chose. Of course some of the older peasants misremembered. Thus, I used a fourth, grouporiented interview method in order to better jog peasant memory, interviewing the same aged peasants I already had interviewed privately in a group context, with three to six villagers. I focused on the political life history of only one person among those present, drilling him and asking him and his fellow villagers questions about his past. The logic of this strategy is obvious: many old peasants have not thought about, or talked with others about, their pre-1 949 protest activities for fifty years. By bringing old friends together in group interviews, I could nudge one man to help another think harder about hazy memories, thereby frequently stimulating individual memory through a free-wheeling group discussion and exchange.

This group interview method had to be carried out in a way that allowed me to comprehend the relationship between family memory and smallgroup memory. In bringing peasants of different households together to 
access their collective group memory, I was careful to note whether they were independently translating group remembrances of local history into images, terms, and insights that lifted them to consonance. ${ }^{10}$ I paid special attention to whether they, as individuals, identified with and embraced a pattern of group remembrances without tutoring from local party leaders and took precautions not to interview peasants for the first time in a group context and not to permit a handful of party ideologues to take over and dominate the group interviews. Also, I was careful to avoid arranging group interviews solely in the household or courtyard of the CCP village secretaries (though in the immediate aftermath of the Tiananmen Square incident this proved to be a delicate and difficult task in one village where I had not previously interviewed).

Finally, I employed a number of procedures to control for lying. I made it a point to interview about 10 percent of the peasants with good memories two, three, and four times, so that I could check their original stories as well as collect new information. I also cross-checked, and attempted to corroborate, information gleaned from villagers against three different sources: other peasants interviewed in the same village unit; former CCP leaders who had grown up in the villages but who had left the countryside to take up positions in the PRC government in Beijing, Zhengzhou, and Tianjin after 1949; and documents, manuscripts, and handwritten notes.

Another aide to detecting lying or wild exaggeration involved nonverbal political communication among villagers participating in small-group interview sessions. The animated reactions of the older peasant saltmakers to the overblown melodrama being mouthed by some of the interviewees-raised eyebrows, mutual glances of disbelief, and contemptuous head shakingsignaled a respondent had departed substantially from reality. This was another advantage of intensive, long-term group interviewing.

When a footnote to the text takes a form that reads "Liu Chaoyang, Qi Ji, $8 / 9 / 90$," such a note is telegraphing the reader that I am relying on an oral interview conducted during my trips to China-Qi Ji village on August 9, $199^{\circ}$. Such a reference is a signal to the reader that peasants are speaking their own history and that something other than the censored Chinese publications that govern so much of Western scholarship on rural life is at work. This system of footnoting, along with signals in the text itself, is what disaggregates the oral from the written documentation underlying the argument, and the reader is encouraged to consult the endnotes in order to ascertain when the oral history is coming into play.

The dictates of length required that I cut vast portions of the oral history materials from the final version of the manuscript; further, a lot of oral history evidence I have gathered did not find its way into the original longer version of Salt of the Earth, so that an even greater evidentiary oral history data base underlies the narrative and interpretation presented here. This 
oral history evidence is composed of handwritten interviews that are stored in my home library. At some point these data will be deposited in an appropriate American university library and will be accessible to other scholars who are serious students of China's agrarian politics and history.

The process of oral interviewing underwent a gradual transformation during the tenure of my project. Essentially, I began with a set of rather stilted printed Chinese questionnaires about peasant life and village economy; moved to a second, more flexible mode of printed Chinese interviews that asked villagers to place their everyday life experiences, including forms of resistance and protest, in the context of political events and processes unfolding in the border area between 1915 and 1949; and then graduated to a mode of informal, open-ended interviewing that often abandoned structured printed Chinese questions and patiently allowed village respondents to rework questions in ways that took me down paths I had not intended to explore and brought me into new, unanticipated streams of local knowledge about politics, society, and economy. Each of these different interview modes was grounded in and/or generated hundreds of questions, so it would be impossible to print them in an appendix. Nevertheless, I am willing to share the oral history questionnaires as well as the oral history raw notes with other specialists, many of whom have not had the privilege of interacting with rural people who helped shape the pre-1949 revolutionary process. 
